\title{
It Is not the Awareness But the Familiarity! Revisiting Private Labels' Brand Equity: An Abstract
}

\author{
Carmen Abril and Belen Rodriguez-Canovas
}

\begin{abstract}
Interest in private labels has increased and identifying factors that build private labels' brand equity is a priority for academics and retailers (De Wulf et al. 2005; Cuneo et al. 2012). However, research into private labels' brand equity is very recent and the few existent studies have not been able to empirically contrast the difference between brand awareness and brand associations (Beristain and Zorilla 2011; Cuneo et al. 2012; Calvo-Porral and Lévy-Mangin 2014).

Are the dimensions of private labels' brand equity the same as those of manufacturer brands' brand equity? Do retailers need to manage private labels the same way manufacturers manage their brands to enhance their brand equity?

The purpose of this research, which is part of broader research, is to examine private labels' equity structure from a brand awareness perspective. We extend Aaker's conceptual model and propose a theoretical adaptation to the particularities that make private labels different from manufacturer brands. This research will contribute to existing literature by (a) clarifying the role of brand awareness in private label brand equity formation and (b) shedding light on how private labels are built in consumers' minds.

The awareness dimension can be defined either as consumers' ability to be reminded of or to recognize the brand by its extrinsic cues in a particular product category or as the ability to recognize or recall a brand when they are exposed to a given product category (Rossiter and Percy 1987). Aaker (1991) suggests that brand awareness has different levels that reflect the predominance of the brand in consumers' minds, such as brand remind, top of mind, and brand opinion (Aaker 1996). Agarwal and Rao (1996) suggest that brand awareness should be approached as recognition and familiarity.

Our results support the idea that traditional conceptualizations of brand equity should be adapted to understand how private labels' brand equity is built. Our findings reveal that in the case of private labels, brand equity is not influenced by pure recognition but by consumers' familiarity with and associations to the brand. Managerial and academic implications are discussed.
\end{abstract}

References Available Upon Request

C. Abril $(\bowtie) \cdot$ B. Rodriguez-Canovas

Complutense University of Madrid, Madrid, Spain

e-mail: cabril@ccee.ucm.es; belen.canovas@gmail.com 